\title{
LITHIUM RECOVERY OF SPENT LITHIUM-ION BATTERY USING BIOLEACHING FROM LOCAL SOURCES MICROORGANISM
}

\author{
M. Hartono, M. A. Astrayudha, H. T. B. M. Petrus*, W. Budhijanto \\ and $H$. Sulistyo \\ Department of Chemical Engineering, Universitas Gadjah Mada, Yogyakarta-55281, Indonesia \\ *E-mail: bayupetrus@yahoo.co.id
}

\begin{abstract}
Lithium-ion battery (LIB) is the most-used battery as a power source due to its high-energy density. Unfortunately, proliferating consumption of LIB incurs in the increasing number of spent LIB in the ecosystem which contains hazardous chemical substance especially lithium and cobalt. This phenomenon forces the extraction of lithium from spent LIB to grow accordingly, even more so as the demand for LIB for various electronic devices in Indonesia is still relatively expensive. Extraction method using bioleaching, which utilizes microorganism as leaching agent offers many attractive advantages. To name a few, bioleaching has higher efficiency, low operating cost and more effective for low concentration of lithium extraction as in spent batteries. This research aims to isolate local bacteria strains, which are able to extract lithium from spent LIB and to determine optimum condition for bioleaching by bacteria. Bacteria strains were isolated from lava tour area, Mount Merapi, Yogyakarta and tannery wastewater in Piyungan, Bantul. After incubation process, bacteria were mixed with spent LIB powder. Lithium recovery was determined by analyzing the filtrate after previously undergoing centrifugation by using ICP quantometer. The result of this experiment shows that bacteria strains isolated from Mount Merapi soil have optimum lithium recovery percentage amounting to $62.83 \%$ after 15 days, with soil/battery mass ratio of $100 \mathrm{~g} / 100 \mathrm{~g}$ and operating condition as follows: pulp density: $2 \mathrm{mg} / \mathrm{mL}$, initial $\mathrm{pH}: 7$, temperature: $30^{\circ} \mathrm{C}$, stirring velocity: $120 \mathrm{rpm}$. Moreover, it was found that adaptation of bacteria with $\mathrm{LiCl}$ solution can increase leaching selectivity of bacteria towards $\mathrm{Li}$. Bacteria strains isolated from Mount Merapi soil were found to exhibit the most potential to be developed as a bioleaching agent. Keywords: bacteria, bioleaching, coupled plasma quantometer, lithium, and lithium-ion battery.
\end{abstract}

(C) RASĀYAN. All rights reserved

\section{INTRODUCTION}

Lithium-ion Battery (LIB) is the most-used battery as a power source due to its high energy density (200 $\mathrm{Wh} / \mathrm{kg}$ ) and recharge efficiency amounting to $90 \%$. LIB mostly applied as a power source in the electric car, laptop, and another kind of electrical equipment. Which is predicted in 2025,400,000 tones LIB produces and LIB market is increasing $15 \%$ per year. Unfortunately, proliferating consumption of LIB incurs in the increasing number of spent LIB in the ecosystem which contains hazardous chemical substance especially lithium and cobalt. Within 100 years lithium and cobalt from spent LIB are completely unraveled. This phenomenon forces the extraction of lithium from spent LIB to grow accordingly. Spent LIB is predicted contain cobalt (5-15\%) and lithium (2-7\%). Valix et al. ${ }^{1}$ studied technology for lithium extraction is pyrometallurgy and hydrometallurgy which dangerous for the environment, costly, and risky. Both of them are recorded causing death to more than 9.000 people because of the mine disaster. Ehrlich ${ }^{2}$ studied extraction method using bioleaching, which utilizes microorganism as leaching agent offers many attractive advantages. To name a few, bioleaching has higher efficiency, low operating cost, raw material abundancies, more safety, and more effective for low concentration of lithium extraction as in spent batteries. Moreover, Firmansyah et $\mathrm{al}^{3}$ studied microorganism diversities in Indonesia reach 120,000 species and this research aims to isolate local bacteria strains, which are able to extract lithium from spent LIB and to determine optimum condition for bioleaching by bacteria. The bacteria strains were isolated from lava tour area, Mount Merapi, Yogyakarta and tannery wastewater in Piyungan, Bantul as local sources of microorganism. 


\section{Materials and Methods}

\section{EXPERIMENTAL}

Materials used in this research include bacteria isolate, cultivation medium, and spent LIB. Bacteria were isolated from soil and mud sample in lava tour area, Mount Merapi, and tannery wastewater in Piyungan, Bantul D.I.Yogyakarta. Cultivation medium includes meat extract (Merc \& Co., molecular biology grade), peptone (Merc \& Co., molecular biology grade), and $\mathrm{NaCl}$ (Merc \& Co., molecular biology grade). Another material such as $\mathrm{LiCl}$ (Merc \& Co.) and $\mathrm{CoCl}_{2}$ (Merc \& Co.) were used for bacterial adaptation and nutrient agar (Merck and Co.) as bacteria media.

The method of experiments consists of spent Lithium-ion battery preparation, bacteria isolation, bacteria cultivation, and accumulation of lithium and cobalt and bioleaching. Bacteria cultivation method and accumulation of lithium and cobalt is based on a method developed by Tsuruta ${ }^{4}$.

\section{General Procedure}

Spent LIB was dismantled by soaking $10 \mathrm{LIBs}$ in $\mathrm{NaCl} 10 \mathrm{~g} / \mathrm{L}$ solution for 1 hour. Dismantling was continued by peeling the metal sheet and separating cathode, anode, and separator of LIB. The active material of cathode $\left(\mathrm{LiCoO}_{2}\right)$ was then separated from the aluminum sheet by crushing.

Soil and mud sample as much as 100 grams were extracted. The samples were diluted with the variation of $10^{2}, 10^{4}$ and $10^{6}$ times dilution using deionized water. Each sample variation was then undergone streaking process in nutrient agar media.

Culture medium for bacteria consists of $3 \mathrm{~g} / \mathrm{l}$ of meat extract, $5 \mathrm{~g} / \mathrm{l}$ of peptone and $5 \mathrm{~g} / \mathrm{l}$ of NaCl. Samples were dissolved in deionized water and grew in the aerobic and anaerobic condition in this media in shakerincubator with stirring velocity about $120 \mathrm{rpm}$ for 72 hours at $30^{\circ} \mathrm{C}$. After that, samples were centrifuged and washed with deionized water.

Bacteria sample for $20 \mathrm{mg}$ (dry basis) was suspended in $100 \mathrm{~mL} \mathrm{LiCl}$ solution with pH 5.8 and $576 \mu \mathrm{M}$ lithium. The solution was stirred for 1 hour at ambient temperature. The bacteria were separated from the solution. The metal ion concentration was counted by coupled plasma quantometer (ICPS8000). A similar procedure was performed for $\mathrm{CoCl}_{2} 576 \mu \mathrm{M}$.

After 3 days of incubation, unadapted bacteria, Li-adapted, and Co-adapted sample were centrifuged at $5,000 \mathrm{rpm}$ for 15 minutes at room temperature. As much as $20 \mathrm{mg}$ of dry bacteria were suspended in $50 \mathrm{~mL}$ medium with $\mathrm{pH}$ 7. The LIB waste powder was suspended in solution to get pulp density for $2 \mathrm{mg} / \mathrm{ml}, 3$ $\mathrm{mg} / \mathrm{ml}$, and $4 \mathrm{mg} / \mathrm{ml}$. The sample was then incubated for 15 days in a shaker-incubator with $120 \mathrm{rpm}$ at $30^{\circ} \mathrm{C}$. Similar procedures were done for incubated bacteria in 7 days and bacteria mass/battery mass ratio of $20 \mathrm{mg} / 100 \mathrm{mg}$, $40 \mathrm{mg} / 100 \mathrm{mg}, 60 \mathrm{mg} / 100 \mathrm{mg}$, and $80 \mathrm{mg} / 100 \mathrm{mg}$.

\section{Detection Method}

The detection method is including coupled plasma quantometer (ICPS8000), scanning electron microscope (SEM) instrument and gram-staining analysis. In the accumulation of lithium and cobalt experiment, the amount of metal accumulated by the cells was determined by measuring the metal content in the filtrate using an inductively coupled plasma quantometer (ICPS8000, Shimadzu Corporation, Kyoto). While, gram-staining provides preliminary results on whether bacteria are present and the general type, such as the shape and whether they are gram-positive or gram-negative. This analysis may also be performed as part of the evaluation of a culture. And the SEM uses a focused beam of high-energy electrons to surface of solid and reveal information about external morphology and orientation of materials in recovered lithium.

\section{RESULTS AND DISCUSSION}

Bacteria produce metabolic secrecy, the optimum condition is determined by trial and error. The maximum bacteria metabolic secrecy was at $10^{4}$ time dilution in which all sample was treated in anaerobic condition. Metabolic secrecy is an indicator of bacteria activity in bioleaching in various dilution conditions. On the other hand, the result of gram-staining analysis indicates that entire sample is gram-positive bacteria. Bacteria accumulation aims to assay the bacteria ability to consume and accumulate lithium and also bacteria viability under high metal concentration. 
RASĀYAN J. Chem.

Vol. 10 | No. 3 |897 - 903 | July - September | 2017

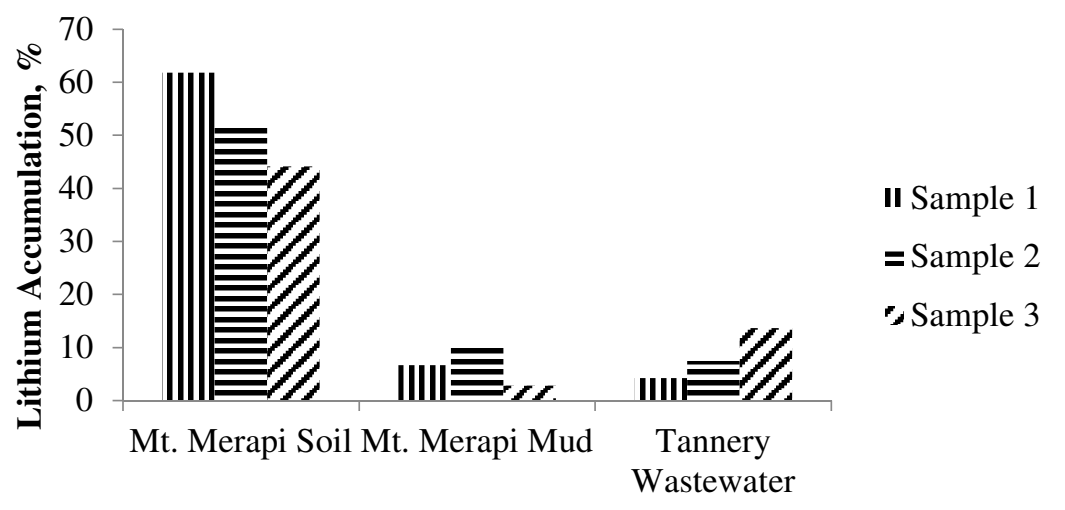

Fig.-1: Lithium accumulation from $\mathrm{CoCl}_{2} 576 \mu \mathrm{M}$ for 1 hour and initial pH: 7.

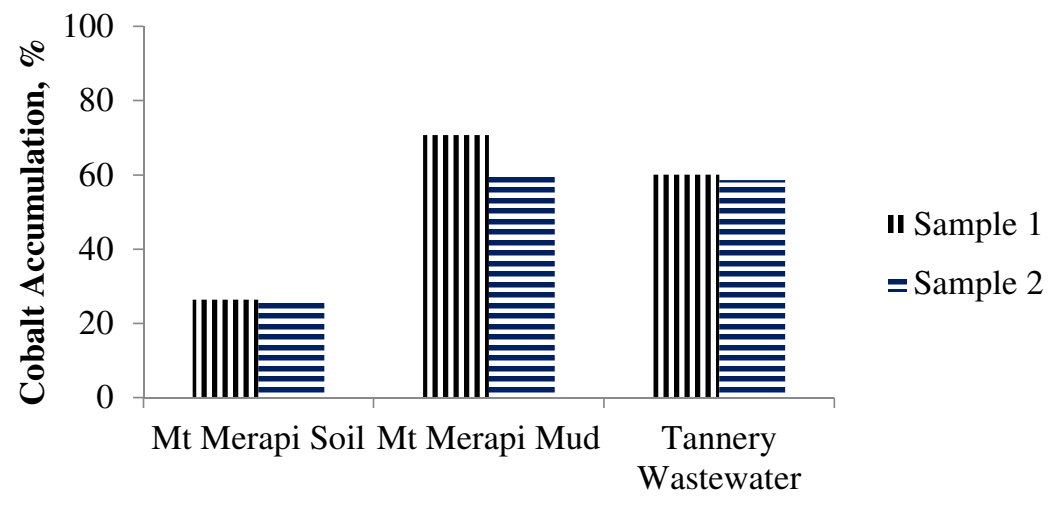

Fig.-2: Cobalt accumulation from $\mathrm{LiCl} 576 \mu \mathrm{M}$ for 1 hour and initial pH: 7.

Based on Figures-1 and 2, the highest lithium accumulation was achieved by Mount Merapi soil sample amounting to $52.47 \%$. Bacteria strain as mixed culture makes difference in accumulation experiment of each sample. The accumulation experiment was also done for $\mathrm{Co}$ in $\mathrm{CoCl}_{2}$ solution. Mount Merapi soil sample achieved the maximum Co accumulation of $65.22 \%$. The optimum condition for this accumulation is at $\mathrm{pH}$ 7. The bacteria strain, which underwent accumulation experiment were later used as Li-adapted and Co-adapted bacteria in bioleaching experiment.

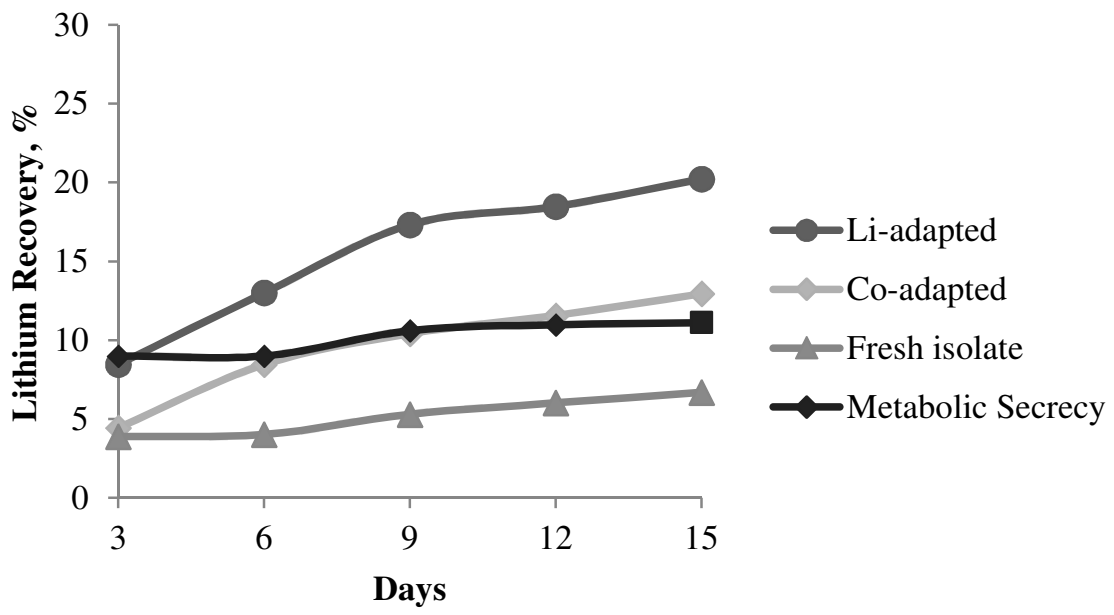

Fig.-3: Lithium recovery by Mount Merapi soil sample (initial pH: 7, stirring velocity: $120 \mathrm{rpm}$, temperature: $30^{\circ} \mathrm{C}$ ) 
RASĀYAN J. Chem.

Vol. 10 | No. 3 |897 - 903 | July - September | 2017

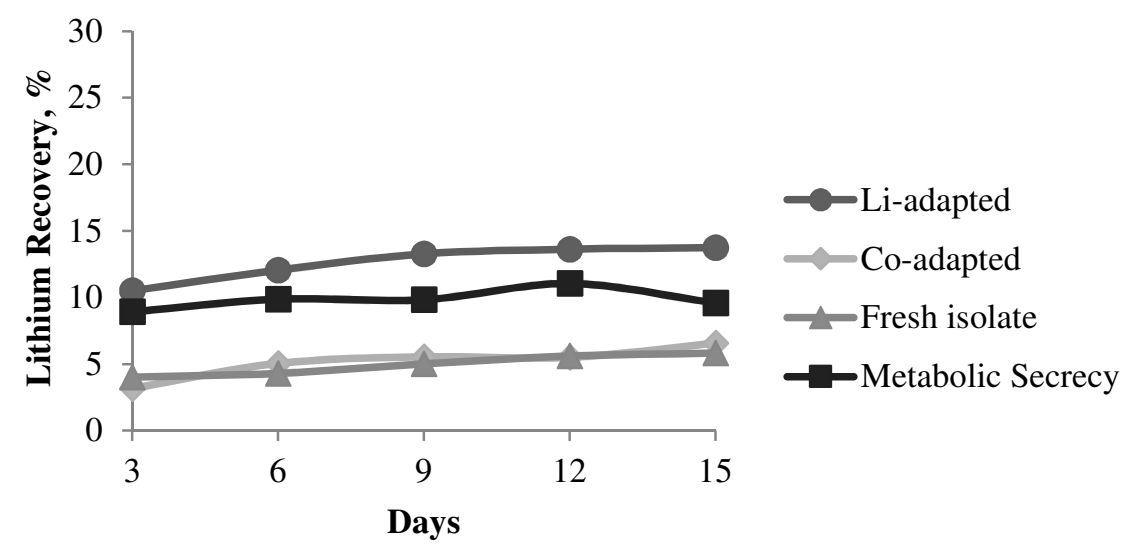

Fig.-4: Lithium recovery by Mount Merapi mud sample (initial pH: 7, stirring velocity: $120 \mathrm{rpm}$, temperature: $30^{\circ} \mathrm{C}$ )

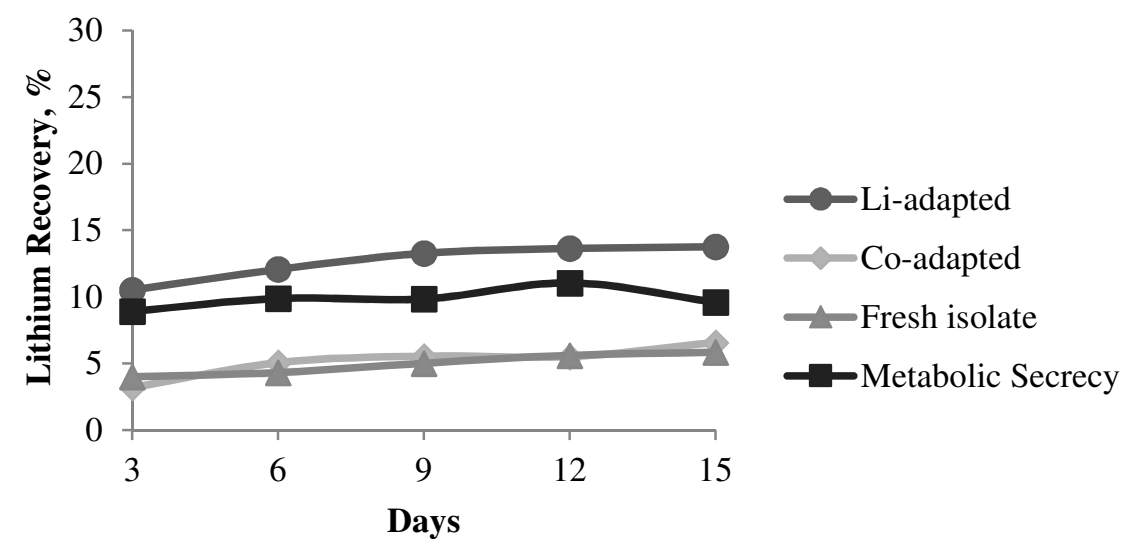

Fig.-5: Lithium recovery by tannery wastewater sample (initial $\mathrm{pH}: 7$, stirring velocity: $120 \mathrm{rpm}$, temperature: $30^{\circ} \mathrm{C}$ )

The bioleaching experiment compares fresh isolate, Li-adapted isolate, Co-adapted isolate and metabolic secrecy. Based on Figures-3, 4 and 5, the highest lithium recovery was achieved by Li-adapted isolate. On the other hand, lithium recovery by metabolic secrecy is higher than fresh isolate. In day three to five, recovery by fresh isolate is constant in all sample. This phenomenon explained by decreasing number of metabolic secrecy. The result indicates bioleaching by using local micro organism is efficient due to continuous metabolic secrecy production. The metabolic secrecy is an acid compound based on titrimetric analysis, which able to dissolute lithium from spent LIB.

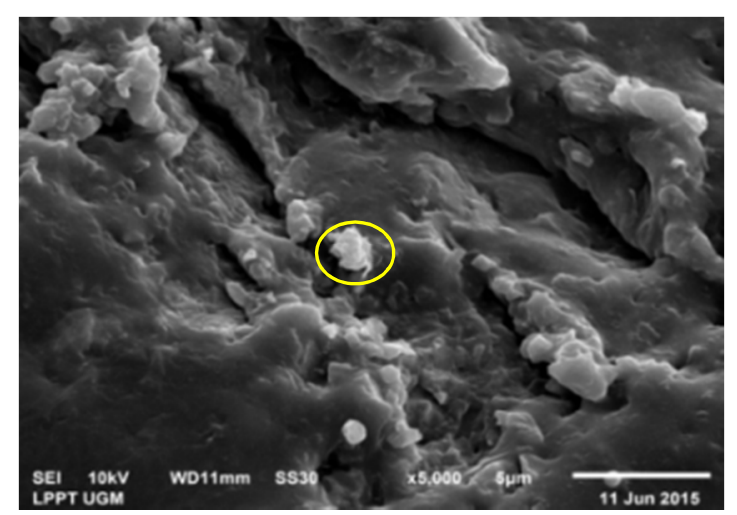

Fig.-6: Scanning Electron Microscope of Mount Merapi soil sample 
Figures-2, 3 and 4 show the order of lithium accumulation from the highest, starting with LiCl solution from Mount Merapi soil sample, followed by tannery wastewater and Mount Merapi mud. On the other hand, it shows the highest lithium recovery achieved by Mount Merapi soil sample, followed by tannery wastewater and Mount Merapi mud. Mount Merapi soil sample is able to recover the highest number of lithium compared to another sample because, in accumulation lithium and cobalt, the bacteria from Mount Merapi soil sample is the most adaptable compared to other samples.

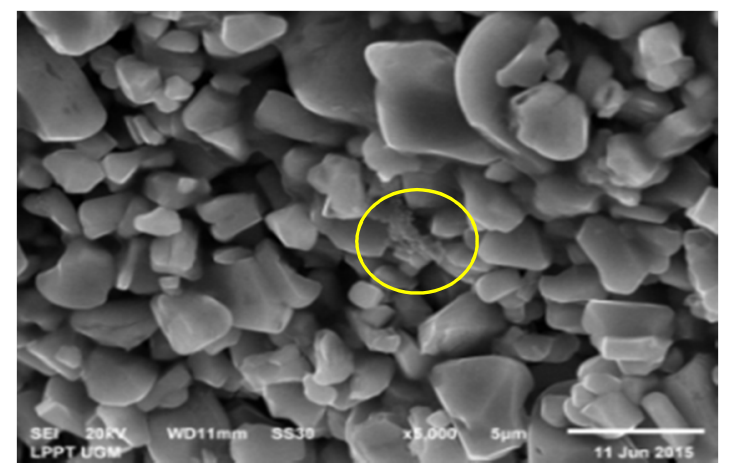

Fig.-7: Scanning Electron Microscope of Tannery Wastewater

The scanning electron microscope (SEM) result shows that bacteria formed an attachment to $\mathrm{LiCoO}_{2}$ crystalline molecules in the leaching solution which leads to lithium extraction. On the other hand, this argument supported by EDX result that shows carbon contain in spent LIB powder after bioleaching. Carbon contains indicate the existence of bacteria that are mostly arranged by a carbon atom.

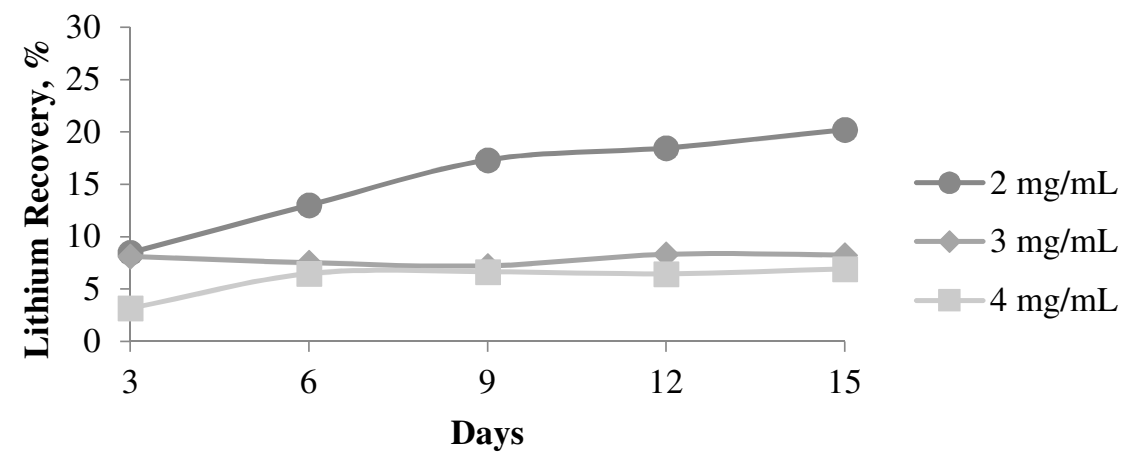

Fig.-8: Lithium recovery by Mount Merapi soil sample for pulp density variation (initial pH: 7, stirring velocity: 120 rpm, temperature: $30^{\circ} \mathrm{C}$ )

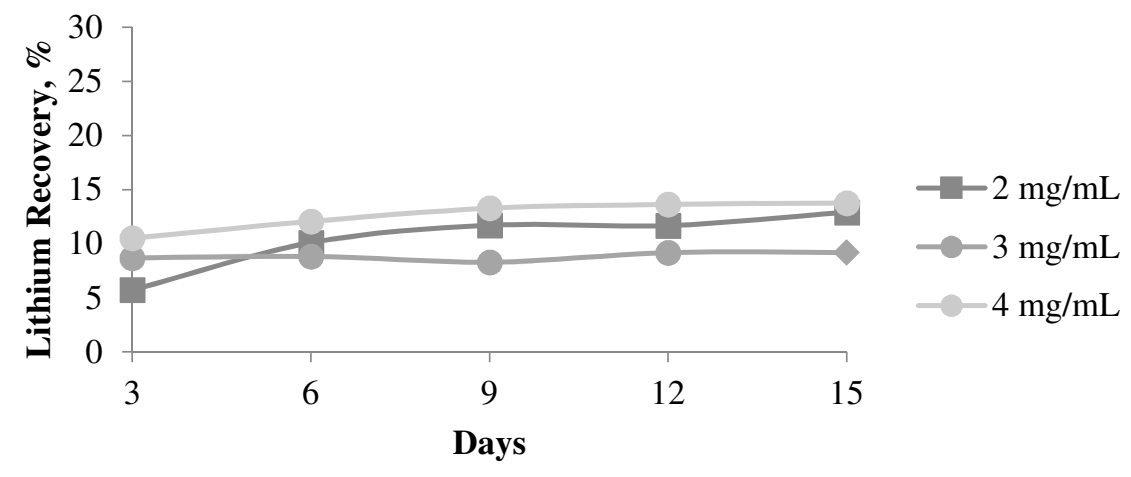

Fig.-9: Lithium recovery by Mount Merapi mud sample for pulp density variation (initial $\mathrm{pH}:$, stirring velocity: $120 \mathrm{rpm}$, temperature: $30^{\circ} \mathrm{C}$ ) 
RASĀYAN J. Chem.

Vol. 10 | No. 3 |897 - 903 | July - September | 2017

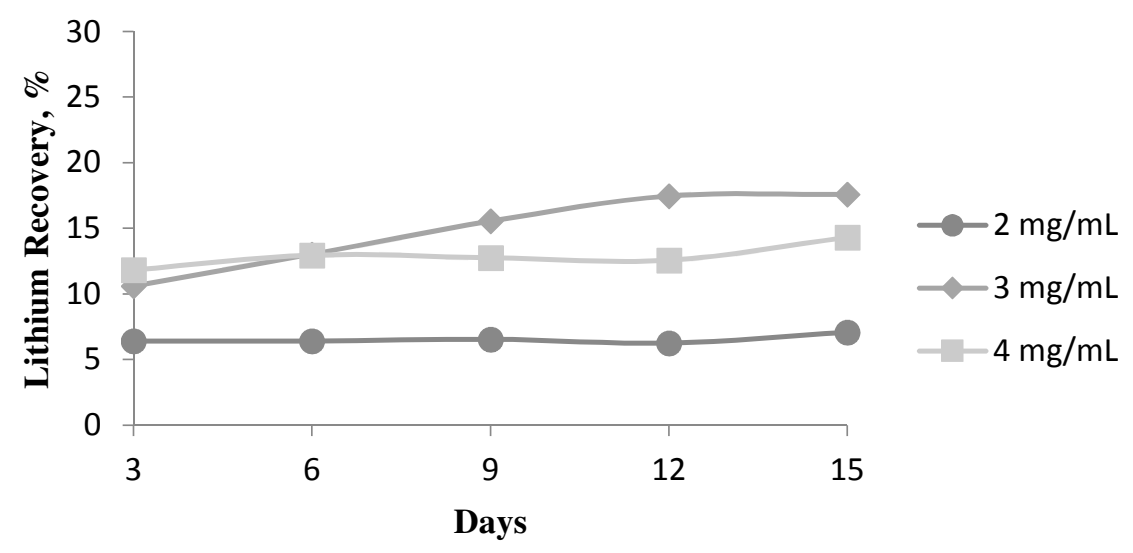

Fig.-10: Lithium recovery by tannery wastewater sample for pulp density variation (initial $\mathrm{pH}$ : 7, stirring velocity: $120 \mathrm{rpm}$, temperature: $30^{\circ} \mathrm{C}$ )

The mass capacity of the battery which is extracted by bacteria for maximum lithium recovery stated as pulp density. Figures-8, 9 and 10, compares the variation of pulp density to the lithium recovery by bacteria. Maximum lithium recovery was achieved by Mount Merapi soil sample for $2 \mathrm{mg} / \mathrm{mL}, 4 \mathrm{mg} / \mathrm{mL}$ for Mount Merapi mud sample and $3 \mathrm{mg} / \mathrm{mL}$ for tannery wastewater.

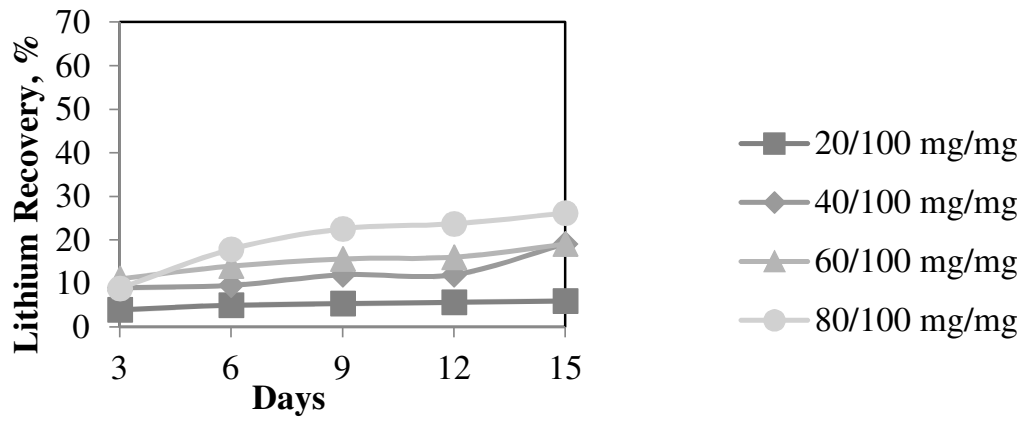

Fig.-11: Lithium recovery in variation of bacteria mass/battery mass, Mount Merapi Soil sample (Li-adapted), pulp density: $2 \mathrm{mg} / \mathrm{ml}$

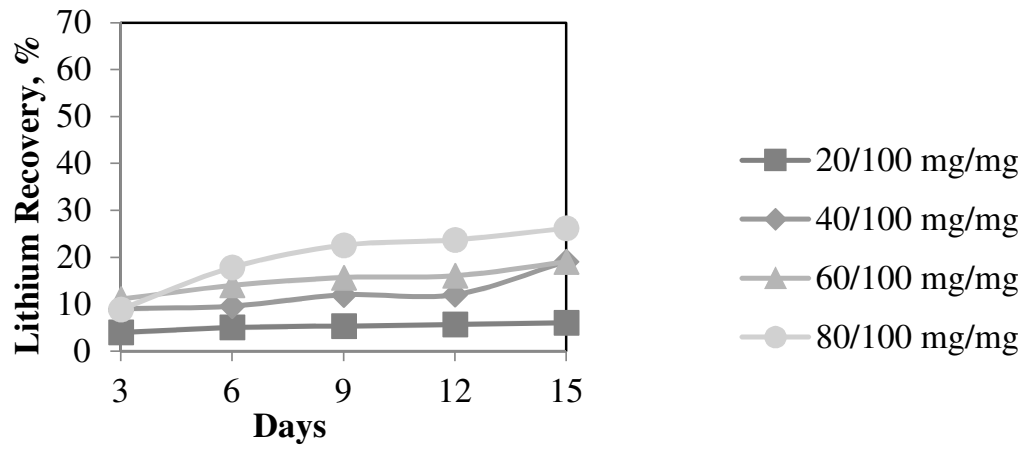

Fig.-12: Lithium recovery in variation of bacteria mass/battery mass, Liquid Waste of Tannery. (pulp density: 4 $\mathrm{mg} / \mathrm{mL}$, initial $\mathrm{pH}: 7$, stirring velocity: $120 \mathrm{rpm}$, temperature: $30^{\circ} \mathrm{C}$ ). 
Figures-11 and 12, illustrates the correlation between the mass ratio of bacteria/battery which is directly proportional to the lithium recovery. The maximum lithium recovery was achieved by Mount Merapi soil sample $(80 / 100 \mathrm{mg} / \mathrm{mg})$ amounting to $55.32 \%$, while tannery wastewater sample $(80 / 100 \mathrm{mg} / \mathrm{mg}$ ) amounting to $26.16 \%$. After 15 days of leaching the lithium recovery by Mount Merapi mud and tannery, wastewater sample is constant. The lithium recovery by Mount Merapi soil sample increased significantly. This phenomenon explained by the growth activity of Mount Merapi soil sample, which is slower compared to another bacteria sources.

\section{CONCLUSION}

A new and facile mixed-strain of bacteria was found to exhibit attractive characteristics for bioleaching of lithium from spent LIB. The optimum lithium recovery was achieved by Mount Merapi mud sample in 15 days anaerobic incubation. Besides being abundantly available, simple and applicable leaching process, bacteria selectivity can be easily adjusted to obtain maximum selectivity for specific metal recovery. With these characteristic, bioleaching becomes a sustainable technology for lithium recovery in spent LIB in the future.

\section{REFERENCES}

1. M. Valix, F. Usai and R. Malik, Mineral Engineering, 14, 197 (2001).

2. H.L. Ehrlich, Geomicrobiology, Marel Dekkar De, New York (1981).

3. R. Firmansyah, A.H. Mawardi and M.U. Riandi, Mudah dan Aktif Belajar Biologi, Setia Purna, Jakarta (2006).

4. T. Tsuruta, Journal of Biosciences, 100, 562 (2005).

[RJC-1767/2017] 